\title{
Teachers' Practices in Using Authentic Assessment in Speaking at Grade IX of SMPN 12 Padang
}

\author{
M. Zaim \\ Lecturers of Faculty of Languages \\ and Arts (FBS) \\ Universitas Negeri Padang
}

\author{
Zul Amri \\ Lecturers of Faculty of Languages \\ and Arts (FBS) \\ Universitas Negeri Padang
}

\author{
Fenni Ronella Asri \\ Student of Graduate Program \\ Universitas Negeri Padang \\ fennironella@gmail.com
}

\begin{abstract}
This research aims to find out about the types of oral language assessment used by the teachers in their practices, the ways in applying those assessment tasks, and the problems faced by the teachers during the assessment processes. The method used in this research is descriptive. The data were collected through interviews to the English teachers of grade IX, distributing the questionnaires to both teachers and two classes of grade IX students, and analyzing the teachers documents. The findings indicate that (1) both teachers have varied the oral language assessment tasks, (2) both teachers have done several procedures of the authentic assessment, however in rating the speaking skill of the students, they still used the same scoring rubrics stated in the lesson plans, meanwhile each of the tasks has its own criteria in rating students' speaking skill.
\end{abstract}

Keywords: Assessment, Authentic assessment, Teachers' practices, Teachers'difficulties, Speaking skill

\section{INTRODUCTION}

The latest curriculum in Indonesia, namely the 2013 curriculum, needs authentic assessment to be applied in assessing students' learning progress in the classroom processes. The reason is because the 2013 curriculum emphasizes both process and product of learning. It means that students are not only expected to master the learning theories, but they are also expected to be able in comprehending and applying those learning theories into the real life situations. In other words, authentic assessment is the right assessment to be used in assessing both process and product of learning.

One of language skills which is really necessary to be developed on students is speaking. Speaking is one of ways in deciding whether they are able in applying theoretical knowledge into practice or not. Because of this reason, speaking is one of language skills which is concerned to be developed on students in the 2013 curriculum. In short, teacher should carry out speaking in the classroom instructions and do the assessment on it authentically.

However in reality, based on the researcher's preliminary research there were still many problems arise related to the oral language assessment practices. One of them was that there were still a few tasks given to students on speaking. Because of this problem, students were not familiar with any oral language assessment activities. Moreover, it was not common for them to practice the language theories into speaking. Although students had understood the theories, they were sometimes still difficult in conveying their ideas in speaking because there was lack of speaking practice. In addition, the common language used by the teachers in teaching English was Indonesian. It also caused students could not develop the new English vocabularies.

In point of fact, the Ministry of Education and Culture (2012: 4) states, the development of the curriculum philosophically is to let students have knowledge, attitudes and skills with them after completing their studies and are able in applying the knowledge in the real life situations. This view is definitely affected the learning approach used in the instructional activities. As many sources mention, the main learning approach used in the instructional activities of the 2013 curriculum is scientific approach. Mu'in et al. (2014: 224) note that there are five principals used in the scientific approach, namely; observing, questioning, experimenting, associating, and communicating.

By using scientific approach, students can develop their creativities because it is more likely to direct students to search for any information of a certain topic themselves instead of having teachers make clear on it completely. In addition, they learn to work in groups or in pairs in order to develop their social competence. Besides, Nur and Madkur (2014: 126) add that scientific approach is used to promote students' critical, analytic, investigational, procedural and communicative competences.

According to the Ministry of Education and Culture (2012: 11), there are two principles in the curriculum development One of them is that the curriculum must be related to the real world contexts. Then, the purpose of assessment in learning is to find out and develop achievement of competence on students. It can be said that the use of scientific approach in the learning processes in the 2013 curriculum is derived from those principles. In addition, the ways in assessing students' learning progress should be authentic, too. Therefore, authentic assessment is applied in the new curriculum.

According to Zaim and Refnaldi (2016), authentic assessment is the way to evaluate students' learning progress through numerous assessment tasks. In addition, Brown (2010: 126) also notes, the belief of authenticity portrays the real-world tasks in which motivate the students to use the language skills in practice more communicatively. Furthermore, Palm (2008: 7) states that in authentic assessment students have to relate their background knowledge to deal with an information needed on the topic and 
express their ideas in detailed. Thus, it can be assumed that the multiple tasks given in authentic assessment should reflect to the real world situations and give a chance to the students to do the tasks meaningfully.

O'Malley and Pierce (1996: 77) note that there are eight types of oral language assessment tasks, namely: (1) oral interview, (2) picture-cued descriptions or stories, (3) radio broadcasts, (4) video clips, (5) information gap, (6) story/text retelling, (7) roleplays, (8) oral reports, and (9) debates. Dealing with those assessment tasks, it seems that picture-cued description, story/text retelling and oral reports tasks are compatible to be used in assessing students' speaking skill when they learn functional/monologue texts. Then, assessment task, like roleplays, seems very common to be used when students learn transactional texts. Additionally, all oral language assessment tasks above can be enjoyable for the students if teachers are able to construct the assessment activities as attractive as possible. By this, students might be more confidence in conveying their ideas orally.

There are several research results related to the teachers' practices in using the authentic assessment. Zaim (2013: 60) notes that in the teachers' practices there were some rubrics which were not appropriate with the skills to be assessed. In addition, the authentic assessment itself was not fully utilized by the teachers. Some teachers often assessed students' progress generally without referring to the scoring rubrics. Moreover, the lack of assessment guidelines and the needs of teacher's training on the implementation of authentic assessment were also noted as the problems in this research.

Besides, Amri (2013: 661) finds that teachers were still hesitant in explaining the concept of authentic assessment in his research. It seems that they did not fully understand what the authentic assessment is. Moreover, Trisanti (2014: 1174) also notes that many teachers did not really have strong concept of authentic assessment. The use of scoring rubric in the assessment was not clear yet for them. Because of that, they needed more training related to the implementation of authentic assessment.

Another finding shown teacher's lack of knowledge in using authentic assessment was also discussed in a research carried out by Khasanah (2015: 66) at grade X of SMAN 1 Rembang. She states that the right methods in applying the authentic assessment have not been determined yet. Therefore there were other non authentic assessment tasks used by the teachers themselves in assessing students' proficiency.

Based on explanation above, this study aims to find out the types of oral language assessment used by the grade IX teachers of SMPN 12 Padang in assessing students' speaking skill. It is also done to find out the ways of teachers in using the assessment tasks in their practices. Some possible problems during the teachers' practices are also discussed in this paper.

\section{RESEARCH METHOD}

The type of research used in this research was descriptive. Schreiber and Asner-self (2011: 15) explain that descriptive studies merely describe phenomenon using numerical data in order to generate a picture of a group or individual. It means that in this research all the findings gathered would be described as what they were. This research was conducted at grade IX of SMPN 12 Padang. There were two teachers and two grade IX classes of students examined in this research. The data were collected through interviews to the English teachers of grade IX, distributing the questionnaires to both teachers and two classes of grade IX students, and analyzing the teachers documents. There were two documents analyzed in this research. They were teachers' lesson plans and syllabuses.

In this research, the data analized were teachers' utterances from the interview, teachers' documents, and both teachers' and students' responses from the questionnaires. In analyzing the data from interview and documentation, the researcher did several steps suggested by Miles and Huberman (1984) in Sugiyono (2011: 334) as the following: data reductions, data display and conclusion. In other hands, in analyzing the data from the questionnaires, the researcher ran SPSS program version 17.

\section{RESEARCH FINDINGS AND DISCUSSION}

The findings discussed in this research are related to the types of authentic assessment used by the teachers in assessing students' speaking skill and the ways of the teachers in using the assessment tasks in their practices. Some possible problems found during the teachers' practices will be discused further.

\section{Types of Authentic Assessment used by Teachers for Assessing Speaking Skill}

There are nine types of oral language assessment suggested by O'Malley and Pierce (1996) - oral interviews, picture-cued descriptions, radio broadcasts, video clips, information gaps, story/text retellings, role plays, oral reports and debates. The types of authentic assessment used by the teachers in assessing students' speaking skill could be seen in the table 1.

Table 1 Types of Authentic Assessment in Assessing Speaking Skill Used by the Teachers at Grade IX

\begin{tabular}{|l|l|c|c|}
\hline No. & \multicolumn{1}{|c|}{$\begin{array}{c}\text { Types of Authentic Assessment in } \\
\text { Assessing Speaking Skill }\end{array}$} & Teacher B \\
\hline 1. & Oral interviews & $\sqrt{ }$ & $\times$ \\
\hline 2. & Picture-cued descriptions & $\times$ & $\sqrt{ }$ \\
\hline 3. & Radio broadcasts & $\sqrt{ }$ & $\times$ \\
\hline 4. & Video clips & $\sqrt{ }$ & $\sqrt{ }$ \\
\hline 5. & Information gaps & $\sqrt{ }$ & $\sqrt{ }$ \\
\hline 6. & Story/text retelling & & \\
\hline
\end{tabular}


Table 1. Cont

\begin{tabular}{|l|l|c|c|}
\hline 7. & Role plays & $\sqrt{ }$ & $\sqrt{ }$ \\
\hline 8. & Oral reports & $\sqrt{ }$ & $\sqrt{ }$ \\
\hline 9. & Debates & $\sqrt{ }$ & $\times$ \\
\hline
\end{tabular}

By looking at the table 1 above, it was found that teacher A has used eight types of oral language assessment tasks in her practices as suggested above, namely; oral interviews, picture-cued descriptions, video clips, information gaps, story/text retelling, role plays, oral reports, and debates. She did not use the radio broadcasts task because it was a new task of oral language assessment for her. In other sides, it was found that teacher B has used five types of the assessment tasks in her practices. They were picture-cued descriptions, information gaps, story/text retelling, role plays, and oral reports.

The questionnaires were also given to the students. There were two classes choosen in this research - IX.2 and IX.6. IX. 2 was handled by teacher A, and IX.6 was handled by teacher B. There were 35 students responded to the questionnaires from IX.2, and there were 34 students responded to the questionnaires from IX.6. The students' responses on the questionnaires about the types of authentic assessment used by the teachers in assessing their speaking skill could be seen in the table 2 .

Table 2 Types of Authentic Assessment Used by the Teachers for Assessing Speaking Skill at Grade IX

\begin{tabular}{|c|c|c|c|c|c|c|c|c|}
\hline \multirow[t]{2}{*}{ No. } & \multirow{2}{*}{$\begin{array}{c}\text { Types of } \\
\text { Authentic } \\
\text { Assessment for } \\
\text { Assessing } \\
\text { Speaking Skill }\end{array}$} & \multicolumn{4}{|c|}{ Response } & \multirow[b]{2}{*}{ స్ㅜㅇ } & \multirow[b]{2}{*}{ 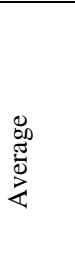 } & \multirow[b]{2}{*}{ 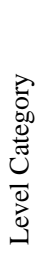 } \\
\hline & & $\begin{array}{l}\overline{0} \\
\grave{0} \\
\bar{z}\end{array}$ & 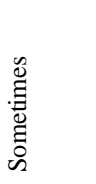 & $\underbrace{\frac{\Xi}{0}}_{0}$ & 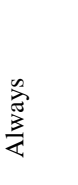 & & & \\
\hline 1. & Oral interviews & $0 \%$ & $\begin{array}{c}(13) \\
18.8 \% \\
\end{array}$ & $\begin{array}{c}(52) \\
75.4 \%\end{array}$ & $\begin{array}{c}(4) \\
5.8 \%\end{array}$ & 198 & 2.86 & $\mathrm{H}$ \\
\hline 2. & $\begin{array}{l}\text { Story/text } \\
\text { retelling }\end{array}$ & $0 \%$ & $\begin{array}{c}(34) \\
49.3 \%\end{array}$ & $\begin{array}{c}(35) \\
50.7 \%\end{array}$ & $0 \%$ & 173 & 2.50 & $\mathrm{~L}$ \\
\hline 3. & $\begin{array}{l}\text { Picture-cued } \\
\text { descriptions }\end{array}$ & $0 \%$ & $\begin{array}{c}(38) \\
55.1 \%\end{array}$ & $\begin{array}{c}(31) \\
44.9 \%\end{array}$ & $0 \%$ & 169 & 2.44 & $\mathrm{~L}$ \\
\hline 4. & Role plays & $0 \%$ & $\begin{array}{c}68) \\
98.6 \% \\
\end{array}$ & $\begin{array}{l}(1) \\
1.4 \% \\
\end{array}$ & $0 \%$ & 139 & 2.01 & $\mathrm{~L}$ \\
\hline 5. & Oral reports & $0 \%$ & $\begin{array}{c}(68) \\
98.6 \%\end{array}$ & $\begin{array}{c}(1) \\
1.4 \%\end{array}$ & $0 \%$ & 139 & 2.01 & $\mathrm{~L}$ \\
\hline 6. & Video clips & $\begin{array}{c}(34) \\
49.3 \%\end{array}$ & $\begin{array}{c}(35) \\
50.7 \%\end{array}$ & $0 \%$ & $0 \%$ & 104 & 1.50 & VL \\
\hline 7. & $\begin{array}{l}\text { Information } \\
\text { gaps }\end{array}$ & $\begin{array}{c}(34) \\
49.3 \%\end{array}$ & $\begin{array}{c}(35) \\
50.7 \%\end{array}$ & $0 \%$ & $0 \%$ & 104 & 1.50 & VL \\
\hline 8. & Debates & $\begin{array}{c}(35) \\
50.7 \% \\
\end{array}$ & $\begin{array}{c}(34) \\
49.3 \% \\
\end{array}$ & $0 \%$ & $0 \%$ & 103 & 1.49 & VL \\
\hline 9. & $\begin{array}{c}\text { Radio } \\
\text { broadcasts }\end{array}$ & $\begin{array}{c}(69) \\
100 \% \\
\end{array}$ & $0 \%$ & $0 \%$ & $0 \%$ & 69 & 1.00 & VL \\
\hline
\end{tabular}

Notes: VL = Very Low, L = Low, $\mathrm{H}=$ High, $\mathrm{VH}=$ Very High

Based on the students' responses, it was indicated that both teachers highly used oral interviews meanwhile picture-cued descriptions, story/text retelling, role plays, and oral reports were in the level category of low to be used in their practices. Then, the use of video clips, information gaps, and debates were in the level category of very low to be used in assessing students' speaking skill. Besides, all of the students also responded that both teachers never used radio broadcasts in their practices.

Actually in assessing students' speaking skill, teacher A had used variety of the assessment tasks. She used eight types of the assessment tasks, except radio broadcasts. In her practices, oral interview, picture-cued description, and video clips were used in teaching transactional texts and functional/monologue texts. However, story/text retelling task was not used in teaching transactional text, but she commonly used it in teaching monologue texts like narrative and recount texts.

In addition, teacher A said that information gap was used in teaching transactional texts and functional/monologue texts. Even so, she admitted that she prefered using information gap task in teaching functional/monologue texts. Then, oral report was used in teaching monologue texts like descriptive, recount, procedure, and report texts. For debate task, she said that she only used it for the topic of agreement. So that, this task was rarely used in her practices.

In other sides, teacher B had used five of the assessment task in her practices, such as; picture-cued descriptions, information gaps, story/text retelling, role plays, and oral reports. In her practices, she did not frequently used assessment tasks like picture-cued descriptions, information gaps, and story/text retelling. Even she seldom used the oral report task. She used picture-cued description task in teaching transactional text while infromation gap was used in teaching monologue text like report 
text. Another task like story/text retelling was used in teaching narrative text. Then, role play was used in teaching transactional texts and oral report task was used in teaching functional text like report. She also said that those tasks were often given to the groups of students - not individual student.In addition, teacher B admitted that she never used oral interviews, radio broadcasts, video clips, and debates in her practices.

Dealing with the explanation above, it is noted that radio broadcasts task was not used at all by both teachers in their practices. Meanwhile, the content of the radio broadcasts links to everyday life. As O'Malley and Pierce (1996: 80) state that this oral language assessment task can encourage the students to speak up, since the topics given are connected to the daily life situations and need students' background knowledge to process the information.

Based on the explanation above it could be said that teacher A had varied the assessment tasks in her practices while teacher B did not really used variety of oral language assessment tasks. In teacher B's practices, some of the assessment tasks were used only in some occassions while some others were never used at all.

\section{The Ways of Teachers Apply the Authentic Assessment for Speaking Skill}

The ways of both teachers assessed students' speaking skill could be as follow:

\section{a. Oral interviews}

Based on the interview results, there were several ways done by teacher A in this task. First, she frequently gave free questions to the students related to the topic which was being learned at the time in her practices. Second, she sometimes gave prepared questions. For the prepared questions, teacher A shared them to the students. Then, she asked the students to answer the questions orally. In contrast, it is noted that teacher B frequently gave free questions to the students in this task. This task was frequently in the form of conversation between the teacher and the students.

\section{b. Picture-cued descriptions}

Dealing with this task, teacher A worked this task by asking students to describe the picture(s) related to the topic which was being learned at the time. Students could describe the phenomenon or the objects shown on the picture(s). Furthermore, teacher A said that she also sometimes asked students to prepare the picture(s) themselves. In other sides, teacher B frequently asked several questions related to the picture(s) shown at the beginning of the activities. Then, she asked the students to note the points which had been discussed in paragraphs. After that, she asked the students to describe the picture(s) in front of the class.

c. Video clips

In doing video clips task to assess students' speaking skill, teacher A started the activities by playing short video(s) using the available media. Then, she asked the students to comprehend the contents of the video(s) given. After the students were ready to tell, then she asked students to give information of the video(s).

\section{d. Information gaps}

Accoring to the interview reults, there were several activities done by teacher A in this task. First of all, teacher A showed two pictures which had some similarites and differences each other to the students. Then, the students were asked to tell the similarities and differences from each of them. In teacher B's practices for this task she firstly devided students into groups and distributed jumble pictures to each of the groups. Then, she asked one of the group members to tell the story of each picture in orders, and asked the other members of the group to arranged the pictures in orders based on the story.

\section{e. Story/text retelling}

In this task, teacher A firstly asked students to read and comprehend the text. After that, teacher A asked the students to retell the stories on the text which they have read. In her practices, teacher B did similar things. First of all, teacher B asked the students to read and discussed the contents of the text in groups. Then, they were asked to write the summaries of the story. After they had been ready, the next step was to ask students retell the story in front of the class.

f. Role plays

According to the findings, in this task both teacher A and B previously decided the topics or situations to be performed in the role play. In deciding the topics or situations to be used in the role play task, teacher A added that she sometimes let the students to choose the topics themselves in order to ease them in preparing the dialogue. Then, both of the teachers asked the students to prepare the dialogue. When the students had been ready, they asked the students to perform the role play in front of the class.

\section{g. Oral reports}

In this task, both teacher A and teacher B firstly asked the students to do an observation about the object which would be presented in this task. They let the students to gather as much as information about the object and chose the important points on it. After that, when the students were ready, they did the presentation.

\section{h. Debates}

In debates task teacher A firstly devided the groups of the students into two sides - pros and cons. Then, teacher A distributed the themes for debating activity to each group of the students and gave the students time to read any available sources before debating. After they were ready, they did the debate activities. 
As mentioned before, both teacher A and teacher B had used several oral language assessment tasks in assessing students' speaking skill. In order to rate the students' mastery in speaking, both teachers used speaking rubrics as stated on the lesson plans. In the first table of the scoring rubrics, there were four scoring aspects used by the teachers, namely: fluency, pronunciation, accuracy, and performance skill. The highest score is 4 for students who can speak fluently and communicatively with correct pronunciation, less grammatical errors in the utterances, and good facial expressions. Meanwhile the lowest score is 1 for students who speak with many pauses, serious errors on grammar, inappropriate vocabularies, and speaking in audible volume. By looking at this, it seems that the scoring rubrics above are still assess the general points on students' speaking. There must be some specific points added because each of oral language assessment tasks has its own criteria in scoring the students' speaking skill.

Another scoring rubrics used by the teachers showed that there are several criteria used by the teachers in assessing students' speaking skill, namely: fluency, intonation, pronunciation, and vocabulary. The highest score used in this rubric is 5 while the lowest is 1 . The details in each criteria still describe the general ways in scoring students' speaking.

By looking at findings, it could be said that both teacher A and teacher B had done the procedures in oral language assessment tasks as suggested by O'Malley and Pierce (1996). However, in rating the students' speaking skill, both of the teachers only used the same scoring rubrics. Meanwhile, according to O'Malley and Pierce, each of oral language assessment tasks has each own scoring rubrics. For example, in oral interview task and picture-cued descriptions task, teacher can use holistic or analytic rating scale to rate students' speaking skill or use a checklist of language skills (O'Malley and Pierce, 1996: 79-80).

According to O’Malley and Pierce (1996: 81), teacher can rate students' comprehension of video clips by determining criteria such as vocabulary, grammar, language functions, and content based on the intsructional goals and activities. For information gaps task, O’Malley and Pierce (1996: 84) devide the rating scores from 1 to 4 . Students who speak using basic vocabulary and expressions, communicating marginally; mostly responding inappropriately or inadequately, using basic structures with frequent errors, and speaking with much hesitation will get the lowest score. In contrast, when students use a variety of descriptive vocabulary and expressions, communicate effectively, almost always responding appropriately and developing the interaction, use a variety of structures with only occasional grammatical errors and speak with little hesitation that does not interfere with communication will get the highest score. The middle score like 3 will be obtained by the students if they use a variety of descriptive vocabulary and expressions, communicate effectively, often responding appropriately and developing the interaction, use a variety of structures with more than occasional errors and speak with some hesitation that does not interfere with communication. Then, the middle score like 2 will be got when the students use some descriptive vocabulary and expressions, communicate acceptably although sometimes responding inappropriately or inadequately or developing little interaction, use a variety of structures with frequent errors or uses basic structures with only occasional errors and speak with some hesitation that interferes with communication.

For story/text retelling task, O'Malley and Pierce (1996: 85) suggest that teacher can rate students' ability by using a holistic or analytic rating scale or checklist of oral language skills. Some important points to be used in rating the students story telling include accuracy in describing the setting, the characters, or a sequence of events; range of vocabulary; and appropriate syntax. In other hands, for role plays task, O’Malley and Pierce (1996: 86) say that teacher can rate the students by referring to these criteria such as language functions, vocabulary, grammar, discourse strategies, clarity of facts presented and non verbal gestures.

For oral report task, O’Malley and Pierce (1996: 87) state that teacher can start assessing students' speaking skill by using rating scale or holistic rubrics which describes the main focus of teaching and adjust it based on students' authentic presentation. Then, for debate task, O'Malley and Pierce (1996: 89) explain that teacher can firstly determine whether she/he wants to assess students individually or in groups. After that, teacher can assess students by using a rating scale or checklist which refers to some certain criteria.

Based on the explanation above, it could be argued that teacher really has to prepare the assessment well before doing it, especially in designing the scoring rubrics and determining the certain criteria used in the assessment. Teacher has to use appropriate scoring rubrics based on the oral language assessment tasks used as suggested by O'Malley and Pierce above.

\section{CONCLUSION}

Based on all of the data analysis about teachers' practices and difficulties in using authentic assessment in speaking at grade IX of SMPN 12 Padang, it could be concluded that:

1. The first teacher has used various types of authentic assessment in assessing students' speaking skill, namely; oral interviews, picture-cued descriptions, video clips, information gaps, story/text retelling, role plays, oral reports, and debates. In contrast, the second teacher did not really vary the authentic assessment tasks in her practices due to some internal and external problems. She only used several oral language assessment tasks, namely; picture-cued descriptions, information gaps, story/text retelling, role plays, and oral reports.

2. So far, the ways of the first teacher used the assessment tasks were good enough. She has almost done what have been suggested by O'Malley and Pierce (1996). In other hand, the second teacher also had done well in some of assessment tasks. However, in rating the students' speaking skill both of the teachers only used the same scoring 
rubrics as stated on the lesson plan. While O'Malley and Pierce (1996) suggest that there are various ways of scoring which should be used according to the each assessment task suggested previously.

\section{References}

Amri, Z. (2013). International Standard Junior High School Fledgling Teachers' Knowledge on Authentic Assessment. Proceeding of the International Seminar on Languages and Arts. Padang: State University of Padang.

Brown, H. Douglas and Priyanvada Abeywickrama. (2010). Language Assessment: Principles and Classroom Practices. NY: Pearson Education

Khasanah, I.R. (2015). The Implementation of 2013 Curriculum by the English Teacher and Its Barriers (A case Study at the 10th Grade of SMA N 1 Rembang in 2014/2015 Academic Year). Semarang: Walisongo State Islamic University

Kemendikbud. (2012). Dokumen Kurikulum 2013. Jakarta: Kementerian Pendidikan dan Kebudayaan Desember 2012

Mu'in, et al. (2014). Implementation of Authentic Assessment. eprints. uny.ac.id.

Nur, M.R. \& Madkur, A. (2014). Teachers' Voices on the 2013 Curriculum for English Instructional Activities. Electronic Journal: 1 (2), $120-134$.

O’Malley, J. Michael \& Pierce, Lorraine Valdez. (1996). Authentic Assessment for English Language leraners: Practical Approaches for Teachers. Addison Wesley Publishing Company

Palm, T. (2008). Performance Assesment and Authentic Assessment: A conceptual Analysis of the Literature. Electronic Journal: 13 (4), 1-11. Practical Assessment, Research \& Evaluation.

Schreiber \& Asner-self. 2011. Educational Research. John Wiley \& Sons, Inc.

Sugiyono. (2011). Metode Penelitian Kombinasi (Mixed Methods). Bandung: ALFABETA, cv.

Trisanti, N. (2013). English Teacher's Perspective on Authentic Assessment Implementation of Curriculum 2013. tHE 61 TEFLIN International Conference. Solo. Semarang State University

Zaim, M., (2013). Asesmen Otentik: Implementasi dan Permasalahannya dalam Pembelajaran Bahasa Inggris di Sekolah Menengah. Proceeding of the International Seminar on Languages and Arts. Padang: State University of Padang.

zaim, M. \& Refnaldi. (2016). Teachers' Need on Authentic Assessment for Speaking Skills. Proceeding International Seminar on Language and Arts (ISLA) 5. Padang: FBS UNP Press. 